American Journal of Applied Sciences 4 (9): 619-627, 2007

ISSN 1546-9239

(C) 2007 Science Publications

\title{
Potential Air and Groundwater Pollution from Continuous High Land Application of Cheese Whey
}

\author{
A.E. Ghaly, D.G. Rushton and N.S. Mahmoud \\ Department of Process Engineering and Applied Science \\ Dalhousie University Halifax, Nova Scotia Canada, B3J 2X4
}

\begin{abstract}
Experiments were performed, using eighteen $280 \mathrm{~cm}$ deep soil columns with $20 \mathrm{~cm}$ inside diameter, to determine the relative amounts of nitrogenous compounds leached and volatilized from soils receiving high application rates of cheese whey during two seasons. Three soils (loamy sand, sandy loam and sandy clay loam) and two cheese whey application rates (560 and $840 \mathrm{~kg}-\mathrm{N} \mathrm{ha}^{-1}$ ), that provided twice and three times the nitrogen requirement for corn crop, were investigated. The leaching and volatilization processes were monitored over a period of five months each season. The concentrations of nitrogenous compounds in the leachates obtained from three soils decreased with time and the soil type and whey application rate did not have any significant effect on the soil removal efficiency of these compounds. However, higher concentrations were observed in the second season of application. The decline in the ammonium nitrogen concentrations in the absence of plants and the initial increase in the nitrite nitrogen and nitrate nitrogen concentrations indicated that the nitrification process had taken place. The organic nitrogen losses in the leachates were $3.02-4.14 \mathrm{~kg} \mathrm{~h}^{-1}(0.54-0.74$ $\%$ of the initial total nitrogen). The total inorganic $\left(\mathrm{NH}_{4}, \mathrm{NO}_{2}, \mathrm{NO}_{3}\right)$ nitrogen losses in the leachates were $59-76 \mathrm{mg}$ which is higher than the initial concentration of $55 \mathrm{mg}$ indicating that the mineralization process had taken place. Volatilization of $\mathrm{NH}_{3}$ was independent of soil type and whey application rate. About $3.41 \mathrm{~g}^{-1} \mathrm{ha}^{-1}$ ( $0.59 \%$ of the initial total nitrogen) of nitrogen was lost to the atmosphere through volatilization Nitrite and nitrate are highly soluble and easily leach out of soil solution. Therefore, continuous application of cheese whey at higher rates may result in ground water contamination and eventually becomes a threat to human and animal health.
\end{abstract}

Key words: Cheese whey, soil, organic nitrogen, ammonium nitrogen, nitrite nitrogen, nitrate nitrogen, ammonia nitrogen, soil depth, air, water, pollution

\section{INTRODUCTION}

Cheese whey is a greenish liquid by-product of the cheese making industry. About $9 \mathrm{~kg}$ of whey are produced for each kilogram of cheese. The whey contains approximately 5\% lactose, $1.5 \%$ nitrogenous compounds, $0.8 \%$ minerals and small amounts of vitamins $^{[1]}$. It has been estimated that approximately 3.1 billion kilograms of whey are produced annually in Canada $^{[2]}$ of which $49 \%$ is used for production of whey powder, $8 \%$ is fed to hogs, $17 \%$ is dumped into sewers and $26 \%$ is disposed of on land $\mathrm{d}^{[3]}$. The dried whey powder industry barely recovers its production cost because of poor market and high energy expenditure and feeding liquid whey to hogs is not economical due to its high trucking cost. Liquid whey can only be used for hog feeding within an economic radius of 30-40
$\mathrm{Km}^{[4]}$. Because of its high BOD value $(40,000-60,000$ $\mathrm{mg} \mathrm{L}^{-1}$ ), whey disrupts the biological process of sewage treatment plants and its disposal to these plants has been banned by many municipalities ${ }^{[5]}$. Thus, land application of whey will, therefore, remain the ultimate end disposal option.

Ghaly et al. ${ }^{[6]}$ recommend that cheese whey should be used as a fertilizer and applied to the land with minimal or no damage to the environment. However, due to the uncertainty in determining the actual nutrient availability, crop producers have been hesitant to rely solely on cheese whey as a source of nitrogen for crop production and have applied excessive amounts of cheese whey. When applied in large quantities at the soil surface, cheese whey will penetrate the soil and move downward. Since the nitrogen in cheese whey is water soluble, it may be subject to leaching, causing

Corresponding Author: Abdel Ghaly, Professor, Process Engineering Department, Dalhousie University, Halifax, Nova Scotia, Canada, B3J 2X4; Tel: (902) 494-6014; Fax: (902) 420-7639 
groundwater pollution. Also, the organic nitrogen will be converted to ammonium, some of which may be lost to the atmosphere causing air pollution. Therefore, more information is needed on the environmental impact of continuous application of large quantities of whey onto agricultural soils. The objectives of this study were to: (a) investigate the whey nitrogen transformation and transport in three Nova Scotian soils receiving high application rates of cheese whey over two seasons and (b) evaluate the impact of continuous high land application of cheese whey on air and groundwater pollution.

\section{MATERIALS AND METHODS}

Experimental apparatus: Eighteen (18) columns were constructed of $20 \mathrm{~cm}$ inside diameter polyvinyl chloride (PVC) pipes. Each pipe was $280 \mathrm{~cm}$ in length and was designed to carry a $250 \mathrm{~cm}$ high soil column as shown in Fig. 1. A $30 \mathrm{~cm}$ headspace was left at the top of each column above the soil for water and cheese whey applications and ammonia volatilization. The inside of the column was lined with coarse sand to minimize the channeling effect. A cap made of $1.2 \mathrm{~cm}$ clear Plexiglas material was fastened to the top of the pipe with screws to protect the column from rain water. Two holes were drilled in each plate and plugged with stoppers, each having a glass tube. One tube (inlet) was used to pump air into the headspace of the soil column whereas the other tube (outlet) was connected to a bottle containing standard acid solution (1 N HCL) for trapping the ammonia released from the cheese whey. Another cap made of $1.2 \mathrm{~cm}$ PVC material was fastened to the bottom of the pipe with PVC cement glue and screws to obtain a water tight fit. A plastic nipple was mounted in a $0.6 \mathrm{~cm}$ diameter hole drilled at the center of the bottom cap which provided a port for the collection of seepage water (leachate). The columns were mounted vertically on the top of a raised steel platform constructed from $2.5 \mathrm{~cm}$ square steel pipes. On the platform directly below each column was drilled a 4.0 $\mathrm{cm}$ diameter hole to allow for the passage of the nipple at the base of each column to facilitate connection to the acrylic tubing and for the positioning of a $3 \mathrm{~L}$ sample bottle for the collection of the leachate from the column.

Soil collection and analysis: Three types of local agricultural soils were used in the study: (a) Stewiacke series, where $50 \mathrm{~kg} \mathrm{acre}^{-1}$ of urea, $75 \mathrm{~kg} \mathrm{acre} \mathrm{e}^{-1}$ of $17-$ 17-17 fertilizer and approximately $1500 \mathrm{~kg}$ of liquid manure are applied annually, (b) Queens series, where $50 \mathrm{~kg} \mathrm{acre}^{-1}$ of urea, $75 \mathrm{~kg} \mathrm{acre}^{-1}$ of 12-24-24 fertilizer

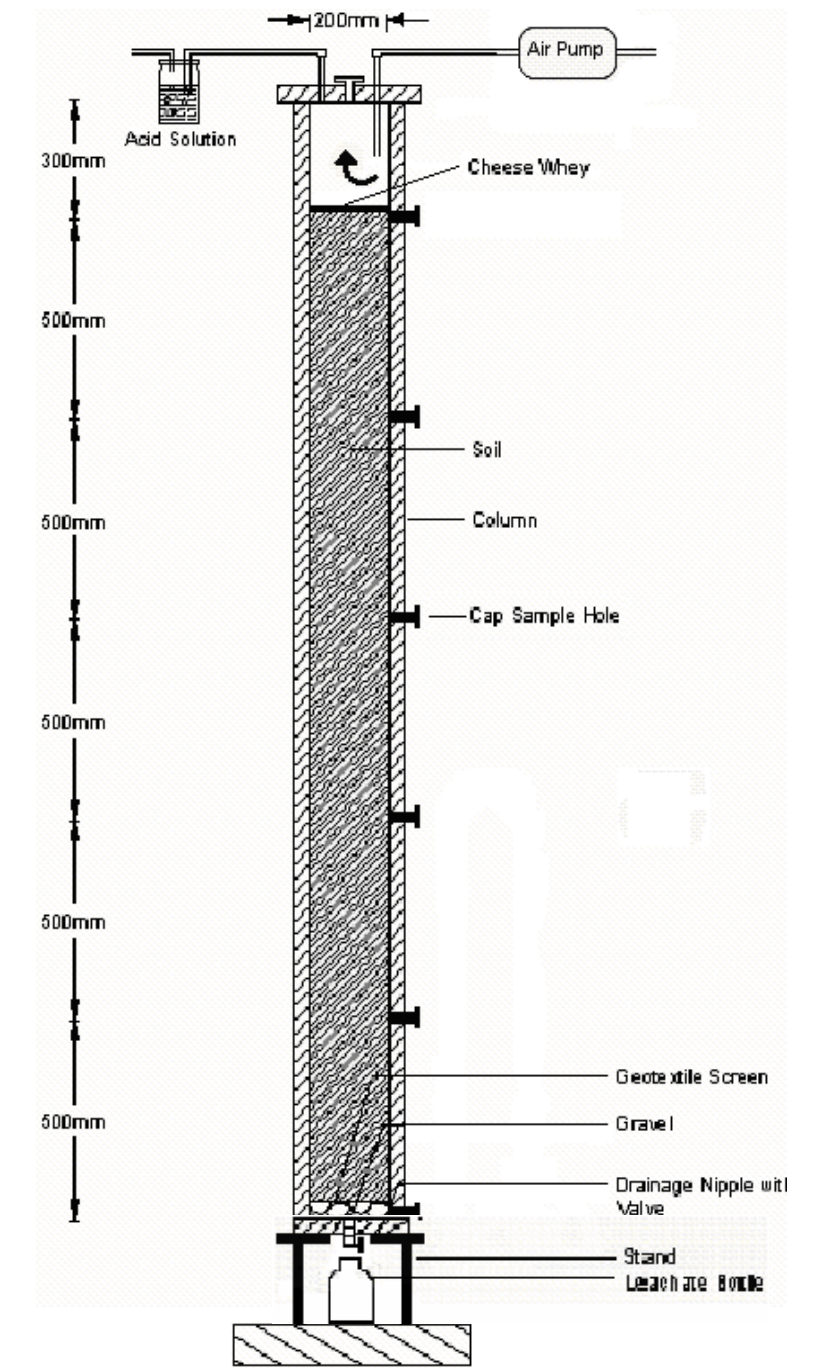

Fig. 1: Schematic diagram of the soil column

and approximately $1500 \mathrm{~kg}$ of liquid manure are applied annually and (c) Kentville series, taken from a virgin land with good crop soil characteristics. At each site, the top vegetal/trash cover of the soil was scraped away and the soil was removed with a shovel from the top $50 \mathrm{~cm}$. About $40 \mathrm{~kg}$ of soils were placed in a heavy duty (16 mm thick) polyethylene bag. Twenty bags were collected from each soil. Bulk density samples were also collected at $30 \mathrm{~cm}$ depth and placed in small plastic bags. All the bags were transported from the collection sites to the Waste Management Laboratory at Dalhousie University in Halifax, Nova Scotia. Each soil type was analyzed to determine field bulk density and particle size distribution. The mechanical and hydrometer methods were used to determine grain size distribution. These tests were carried out according to the procedure described by Black et al. ${ }^{[7]}$. 
Am. J. Appl. Sci., 4 (9): 619-627, 2007

\begin{tabular}{|c|c|c|c|c|}
\hline Series & Texture & \multicolumn{2}{|c|}{ Drainage Class } & $\begin{array}{l}\text { Permeabil } \\
\quad\left(\mathrm{m} \mathrm{h}^{-1}\right)\end{array}$ \\
\hline Kentville & $\begin{array}{l}\text { Moderately } \\
\text { coarse }\end{array}$ & \multicolumn{2}{|c|}{$\begin{array}{l}\text { Moderately } \\
\text { drained }\end{array}$} & Moderate $(0$. \\
\hline Stewiacke & Medium & \multicolumn{2}{|c|}{ Poorly drained } & Moderate $(0$. \\
\hline Queens & Moderately fine & \multicolumn{2}{|c|}{$\begin{array}{l}\text { Imperfectly } \\
\text { drained }\end{array}$} & Slow (0.026) \\
\hline Table 2: & cteristics of the $\mathrm{ch}$ & ese whey & & \\
\hline Parameter & & & \multicolumn{2}{|c|}{ Measured Value } \\
\hline \multicolumn{2}{|c|}{ Total Solids $\left(\mathrm{mg} \mathrm{L}^{-1}\right)$} & \multicolumn{3}{|c|}{56800} \\
\hline \multicolumn{2}{|c|}{ Volatile Solids $\left(\mathrm{mg} \mathrm{L}^{-1}\right)$} & \multicolumn{3}{|c|}{46850} \\
\hline \multicolumn{2}{|c|}{$\operatorname{Ash}\left(\mathrm{mg} \mathrm{L}^{-1}\right)$} & & \multicolumn{2}{|c|}{9950} \\
\hline \multicolumn{3}{|c|}{ Total Chemical Oxygen Demand $\left(\mathrm{mg} \mathrm{L}^{-1}\right)$} & \multicolumn{2}{|l|}{78850} \\
\hline \multicolumn{3}{|c|}{ Soluble Chemical Oxygen Demand $\left(\mathrm{mg} \mathrm{L}^{-1}\right)$} & \multicolumn{2}{|l|}{58040} \\
\hline \multicolumn{3}{|c|}{ Organic Nitrogen $\left(\mathrm{mg} \mathrm{L}^{-1}\right)$} & \multicolumn{2}{|c|}{1765} \\
\hline \multicolumn{2}{|c|}{ Ammonium Nitrogen $\left(\mathrm{mg} \mathrm{L}^{-1}\right)$} & \multicolumn{3}{|c|}{25} \\
\hline \multicolumn{2}{|c|}{ Nitrite Nitrogen $\left(\mathrm{mg} \mathrm{L}^{-1}\right)$} & \multicolumn{3}{|c|}{2} \\
\hline \multicolumn{2}{|c|}{ Nitrate Nitrogen $\left(\mathrm{mg} \mathrm{L}^{-1}\right)$} & \multicolumn{3}{|c|}{28} \\
\hline \multicolumn{2}{|c|}{ Phosphorus $\left(\mathrm{mg} \mathrm{L}^{-1}\right)$} & \multirow{2}{*}{\multicolumn{3}{|c|}{$\begin{array}{l}468 \\
5.9\end{array}$}} \\
\hline \multicolumn{2}{|l|}{$\mathrm{pH}$} & & & \\
\hline
\end{tabular}

\begin{tabular}{lc} 
Table 3: & Average rainfall for Halifax area during growing season ${ }^{[8]}$ \\
\hline Month & Accumulation $(\mathrm{mm})$ \\
\hline May & 55.8 \\
June & 92.2 \\
July & 134.8 \\
August & 103.9 \\
September & 105.7 \\
Monthly Average & 98.5 \\
\hline
\end{tabular}

The three soils were found to be different from one another and were classified as loamy sand, sandy loam and sandy clay loam as shown in Table 1 .

Column preparation and conditioning: Three soils were used and two whey application rates were investigated and three replicates were carried out, resulting in a total of 18 treatments. A $5 \mathrm{~cm}$ crushed gravel zone was constructed on the bottom of each column. A geotextile screen was then laid over the gravels. This was done to permit free drainage and to prevent the soil from clogging the leachate collection outlets. Soils were then placed in layers (approximately $2 \mathrm{~L})$ until the desired height $(250 \mathrm{~cm})$ was reached. Each layer was compacted to achieve field bulk density. The addition of equal volumes of soil and the consistent soil compaction ensured a uniform solid density throughout the column. The infiltrate outlet in each column was closed and the soils were saturated with water to avoid gas trapping in the soil voids. After the soils were saturated with water for three days, the excess water was drained.

Cheese whey collection and application: Cheddar cheese whey was collected from Farmer's Dairy Plant in Truro, Nova Scotia in a $200 \mathrm{~L}$ tank and mixed thoroughly. It was then placed in $40 \mathrm{~L}$ plastic bags and transported to the Waste Management Laboratory at Dalhousie University in Halifax, Nova Scotia where it was stored in a freezer at $-18^{\circ} \mathrm{C}$ until needed. Prior to being applied onto the soil, the bags were removed from the freezer and the cheese whey was allowed to thaw at room temperature for $24 \mathrm{hrs}$. Some characteristics of the cheese whey are presented in Table 2. The application of cheese whey was made based on the assumptions that: (a) the nitrogen requirement for corn crop is $280 \mathrm{~kg}-\mathrm{N} \mathrm{ha}{ }^{-1}$ and (b) only half of the organic nitrogen would be available for the crop during the year of application. The total nitrogen in the cheese whey was $1820 \mathrm{mg} \mathrm{L}^{-1}$, most of it (96.98\%) in the organic form. Thus, the calculation was based on the total nitrogen in whey. Two high application rates were used in the study: 560 and 840 kg-N ha ${ }^{-1}$ (twice and three times the nitrogen fertilizer requirement for corn). About 1.0 and $1.5 \mathrm{~L}$ of whey were required. These amounts were applied onto the soil surface in the designated columns on day 0 of the first and second seasons, respectively.

Rain fall simulation and water application: Using precipitation data issued by Environment Canada ${ }^{[8]}$, the average monthly rainfall accumulations for the months of May to September were calculated as shown in Table 3 . The five-month span was selected on the basis that it represents the average growing/harvesting season in Nova Scotia during which the microbial population in the soil is active. The average monthly rainfall for the period of May to September is $98.5 \mathrm{~mm}$ which is equivalent to $3.1 \mathrm{~L}$ of water per column. The total rainfall accumulation for the five month period $(15.5 \mathrm{~L})$ of each season was applied into each column at a rate of $3.1 \mathrm{~L}$ per month ( $1.55 \mathrm{~L}$ every 15 days). Leachates were collected every 15 days before water applications and analyzed for nitrogenous compounds. 
Analyses: The total solid, chemical oxygen demand, total Kjeldahl nitrogen, ammonium nitrogen, nitrite nitrogen and nitrate nitrogen analyses were performed on the cheese whey. The total Kjeldahl nitrogen, ammonium nitrogen, nitrate nitrogen and nitrite nitrogen analyses were performed on the samples taken from the leachates collected every 15 days. The organic nitrogen was calculated by subtracting the ammonium nitrogen from the total kjeldahl nitrogen. The total solid and chemical oxygen demand tests were performed according to the procedures described in the APHA ${ }^{[9]}$. The nitrogen analyses were performed according to the procedures described in Black et al. ${ }^{[7]}$. Ammonia analysis was performed according to the procedure described by Zein El-Din ${ }^{[10]}$.

\section{RESULTS}

Moisture content: The moisture content results are shown in Fig. 2. The moisture content decreased over time for all cheese whey applications rates and years of application. The moisture content varied with the soil type and was dependent on the structure as well as clay and silt contents of the soil; the higher the clay and silt contents, the higher the moisture content. The average moisture content values obtained at the end of the experiment are presented in Table 4. Generally, Kentville soil (loamy sand) had much lower moisture content than the Stewiacke (sandy loam) and Queens (sandy clay loam) soils. Soils that received higher cheese whey application (840 kg nitrogen per hectare) had higher moisture content than those that received lower cheese whey application $(560 \mathrm{~kg}$ nitrogen per hectare). Also, repeated application of cheese whey appeared to slightly increase the water holding capacity of the soil.

Leachates: The volumes of leachates are presented in Fig. 3. Of the $1550 \mathrm{~mL}$ of water applied each 15 days, only about $640-790 \mathrm{~mL}(42-51 \%)$ were collected, depending on the soil type, cheese whey application rate and year of application. The balance of the water was retained by the soil and/or evaporated. The moisture content results indicated that the higher the whey application rate the higher the water retention by the soil. The volumes of the leachates obtained from the second year were smaller than those obtained from the first year.

Organic nitrogen: The organic nitrogen results are shown in Fig. 4. The organic nitrogen concentration in the whey was $1,765 \mathrm{mg} \mathrm{L}^{-1}$. The concentration of organic nitrogen decreased with time. A maximum
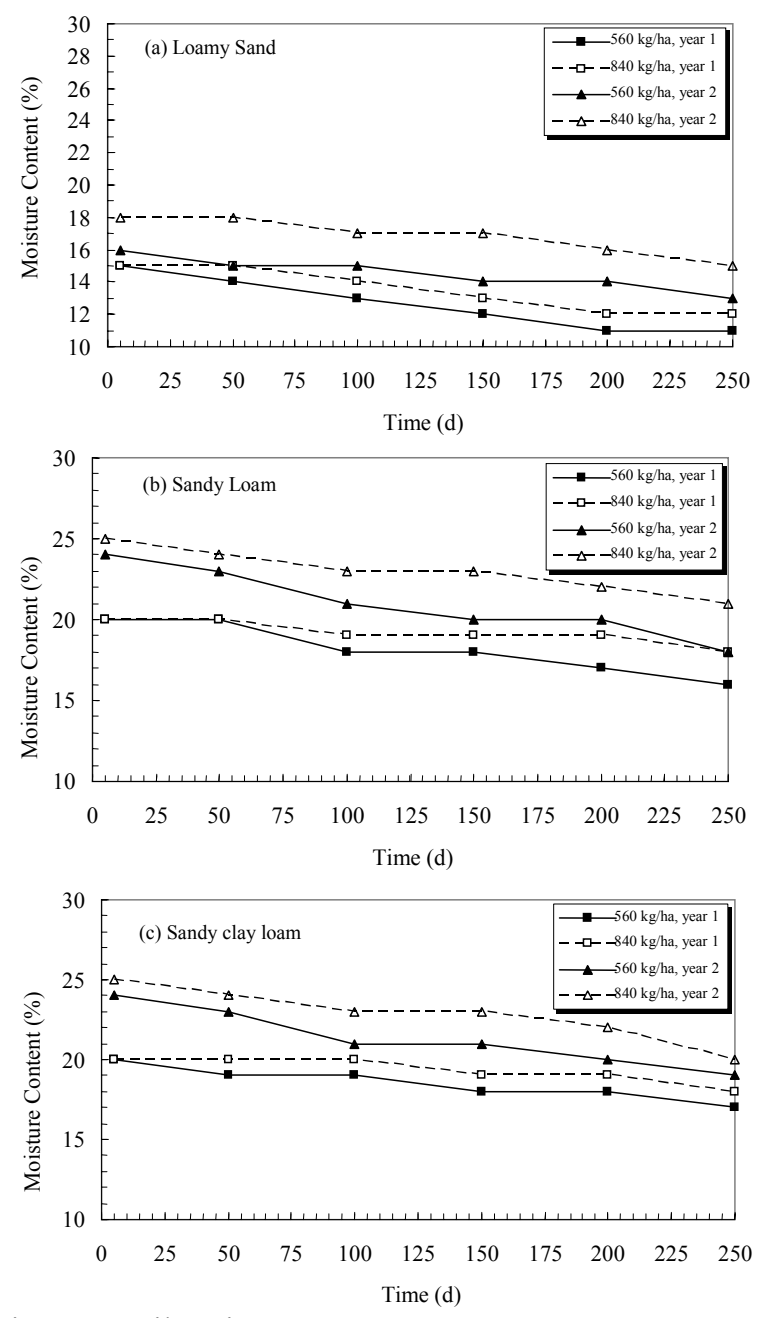

Fig. 2: Soil moisture content

concentration of 2.3-7.7 $\mathrm{mg} \mathrm{L}^{-1}$ of organic nitrogen was found in the leachate samples on day 15 . The soil type did not appear to have any significant effect on the organic nitrogen concentration in the leachates after day 45. The minimum values of organic nitrogen concentration recorded at the end of the experiment were 1.0 and $2.3 \mathrm{mg} \mathrm{L}^{-1}$ for the first and second seasons, respectively. Most of the organic nitrogen in the cheese whey (99.7-99.9\%) was retained by the soil and will, therefore, be made bioavailable to the plant after conversion to ammonium in subsequent years.

Ammonium nitrogen: The ammonium nitrogen results are shown in and Fig. 5. The concentration of ammonium nitrogen in the cheese whey was very low ( $25 \mathrm{mg} \mathrm{L}^{-1}$ or $1.37 \%$ of the total whey nitrogen). The soil type, whey application rate and year of application affected the concentration of ammonium nitrogen in 
Am. J. Appl. Sci., 4 (9): 619-627, 2007
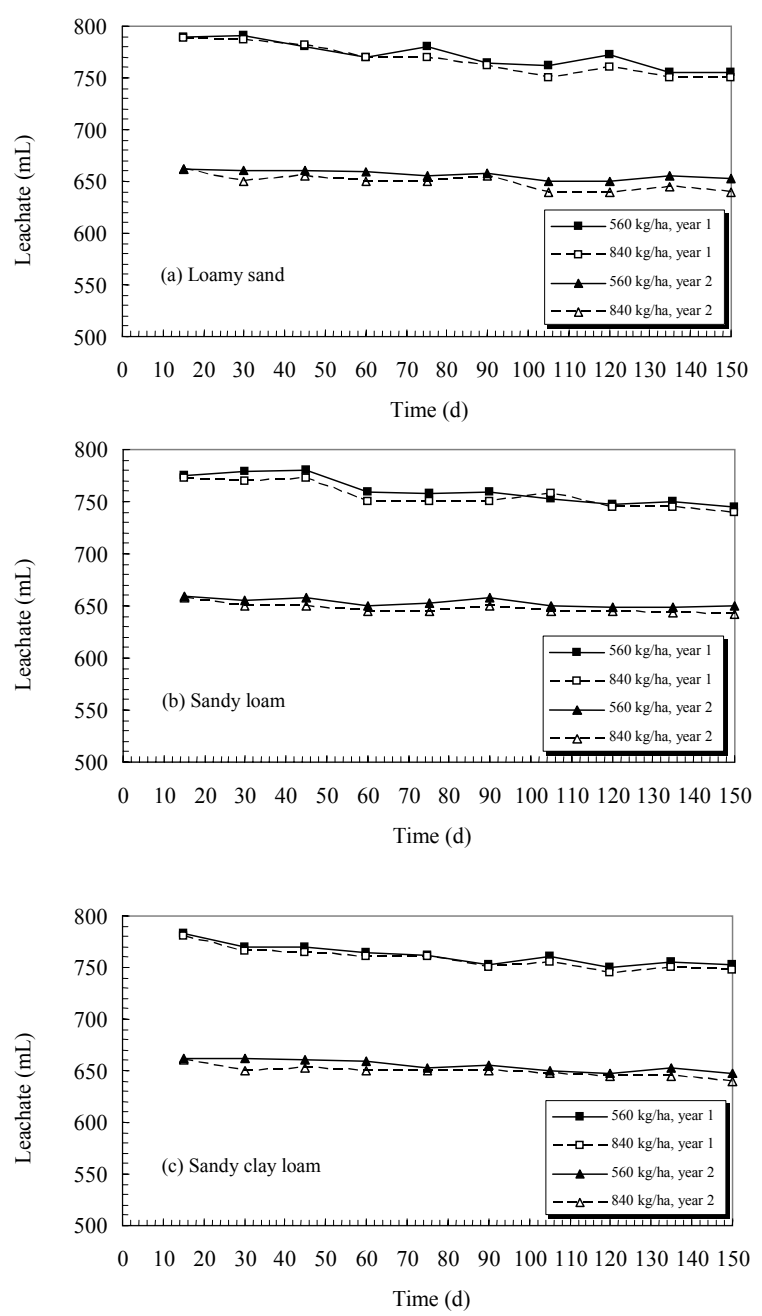

Fig. 3: Leachate volumes

leachates. The ammonium nitrogen concentration in leachates declined gradually until it reached zero for the first season on day 135 and $0.2-0.3 \mathrm{mg} \mathrm{L}^{-1}$ for the second season on day 150. This is an indicator of the presence of nitrifying bacteria which converted ammonium to nitrite and nitrate.

Nitrite nitrogen: The nitrite nitrogen results are shown in Fig. 6. The initial concentration of nitrate nitrogen in cheese whey was $2 \mathrm{mg} \mathrm{L}^{-1}(0.11 \%$ of the total nitrogen). The nitrite nitrogen concentration first decreased to $0.6-0.9 \mathrm{mg} \mathrm{L}^{-1}$ on day 15 , increased with time reaching $1.2-1.5 \mathrm{mg} \mathrm{L}^{-1}$ on day 45 and then declined with time. The soil type did not have any significant effect on the nitrite nitrogen concentration. However, there were differences in nitrite concentrations in the leachates obtained from the two seasons for both application rates.
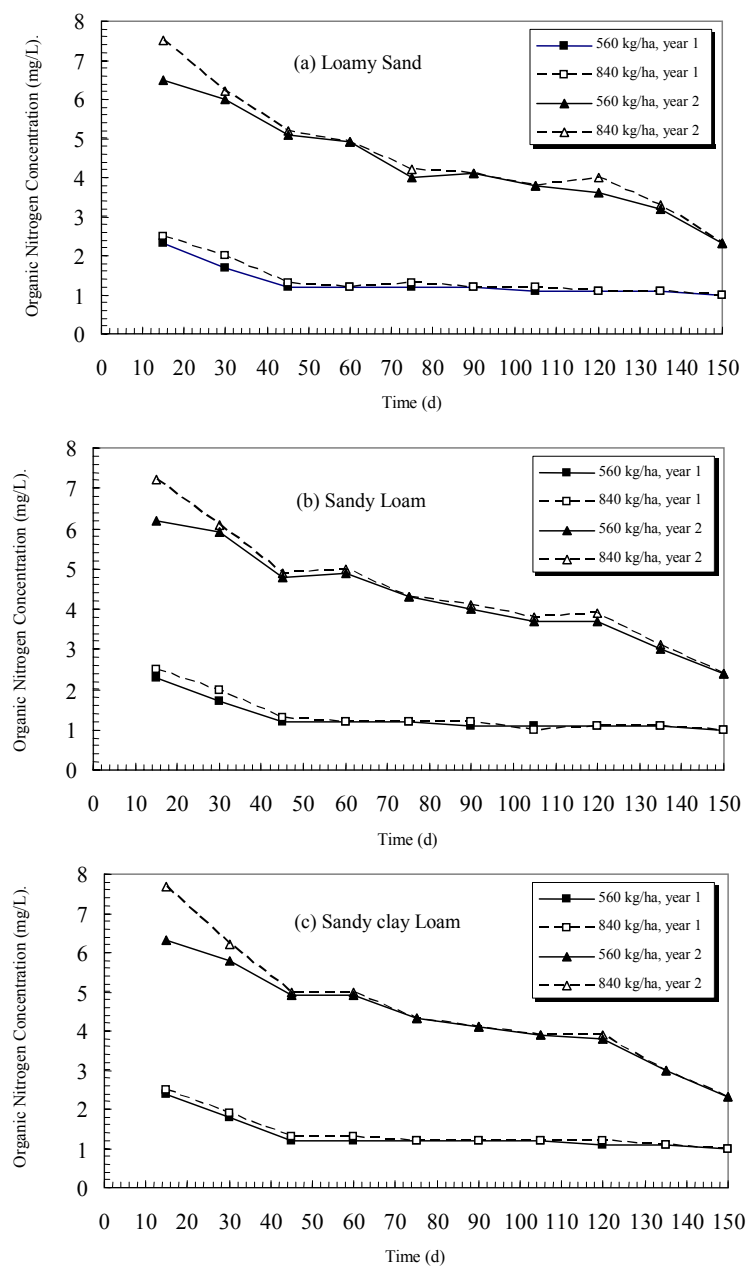

Fig. 4: Organic nitrogen concentration in the leachates

Table 4: Average moisture content at the end of the experiment (day 250)

\begin{tabular}{lllll}
\hline Season & $\begin{array}{l}\text { Application } \\
\text { rate }(\mathrm{kg} / \mathrm{ha})\end{array}$ & $\begin{array}{l}\text { Loamy } \\
\text { sand }\end{array}$ & $\begin{array}{l}\text { Sandy } \\
\text { loam }\end{array}$ & $\begin{array}{l}\text { Sandy clay } \\
\text { loam }\end{array}$ \\
\hline Year 1 & 560 & 11 & 16 & 17 \\
& 840 & 12 & 18 & 18 \\
Year 2 & 560 & 13 & 18 & 19 \\
& 840 & 15 & 21 & 20 \\
\hline
\end{tabular}

Nitrate nitrogen: The nitrate nitrogen concentrations in leachates are shown in Fig. 7. The initial nitrate concentration in the cheese whey was $28 \mathrm{mg} \mathrm{L}^{-1}$ ( $1.54 \%$ of the total nitrogen). The nitrate nitrogen concentrations in the leachates were relatively high at the beginning of the experiment: 5.4-5.5 mg L $\mathrm{m}^{-1}$ for the first season and 9.6-9.7 $\mathrm{mg} \mathrm{L}^{-1}$ for the second season. It first decreased with time and then increased reaching its maximum on day 60 and finally declined reaching 1.0$1.2 \mathrm{mg} \mathrm{L}^{-1}$ for the first season and 4.5-5.2 $\mathrm{mg} \mathrm{L}^{-1}$ for 
Am. J. Appl. Sci., 4 (9): 619-627, 2007

Table 5: Nitrogen losses in the leachate and air

\begin{tabular}{|c|c|c|c|c|c|c|c|c|c|c|c|}
\hline \multirow{3}{*}{ Soil Type } & \multirow{3}{*}{ Whey (Kg/ha) } & \multicolumn{10}{|c|}{ Nitrogen Loss in Leachates $(\mathrm{mg} / \mathrm{L})$} \\
\hline & & \multicolumn{2}{|c|}{ Organic-N } & \multicolumn{2}{|l|}{$\mathrm{NH}_{4}-\mathrm{N}$} & \multicolumn{2}{|l|}{$\mathrm{NO}_{2}-\mathrm{N}$} & \multicolumn{2}{|l|}{$\mathrm{NO}_{3}-\mathrm{N}$} & \multicolumn{2}{|c|}{ Volatilized Ammonia } \\
\hline & & Year 1 & Year 2 & Year 1 & Year 2 & Year 1 & Year 2 & Year 1 & Year 2 & Year 1 & Year 2 \\
\hline \multirow[t]{2}{*}{ Loamy Sand } & 560 & 10.2 & 28.6 & 1.7 & 6.5 & 3.9 & 4.0 & 29.2 & 46.5 & 10.2 & 28.6 \\
\hline & 840 & 10.8 & 29.7 & 2.0 & 6.8 & 4.7 & 4.7 & 30.4 & 46.7 & 10.8 & 29.7 \\
\hline \multirow[t]{2}{*}{ Sandy Loam } & 560 & 9.9 & 28.0 & 1.5 & 5.9 & 3.9 & 4.2 & 28.1 & 45.7 & 9.9 & 28.0 \\
\hline & 840 & 10.3 & 29.1 & 1.8 & 6.4 & 4.6 & 4.7 & 29.8 & 46.6 & 10.3 & 29.1 \\
\hline Sandy Clay & 560 & 10.1 & 28.3 & 1.7 & 5.6 & 4.0 & 4.5 & 27.9 & 45.5 & 10.2 & 28.3 \\
\hline Loam & 840 & 10.6 & 29.6 & 1.8 & 6.5 & 4.3 & 4.8 & 29.7 & 45.5 & 10.6 & 29.6 \\
\hline
\end{tabular}

Values are the average of four replicates each

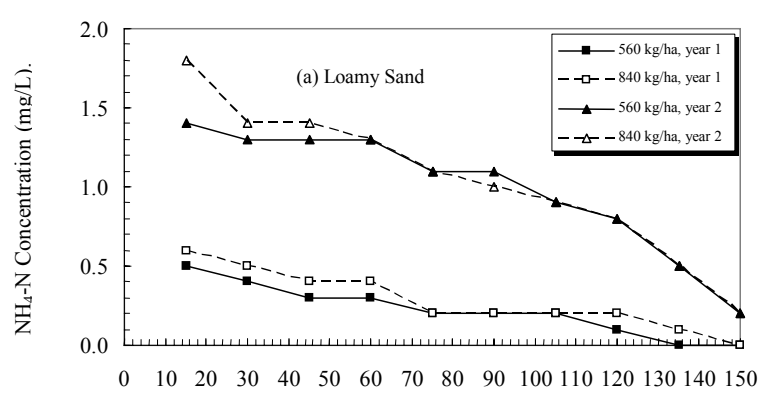

Time (d)
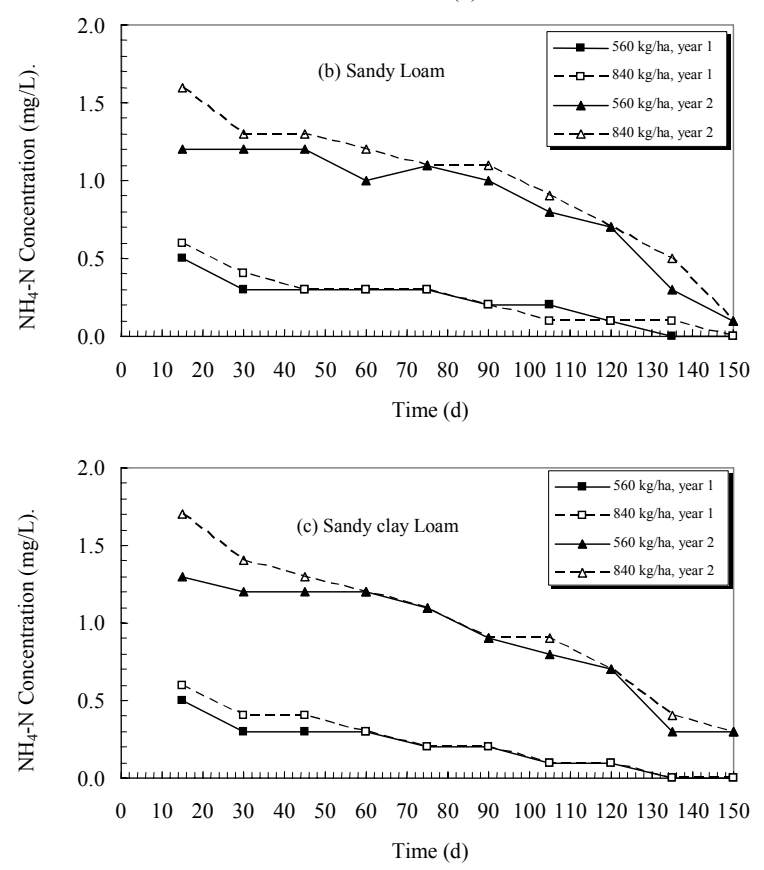

Fig. 5: Ammonium nitrogen concentration in leachates

the second season by the end of the experiment. The soil type did not affect the concentration of nitrate nitrogen in the leachates. However, both the why application rate and year of application affected the concentration of $\mathrm{NO}_{3}-\mathrm{N}$ in the leachates.
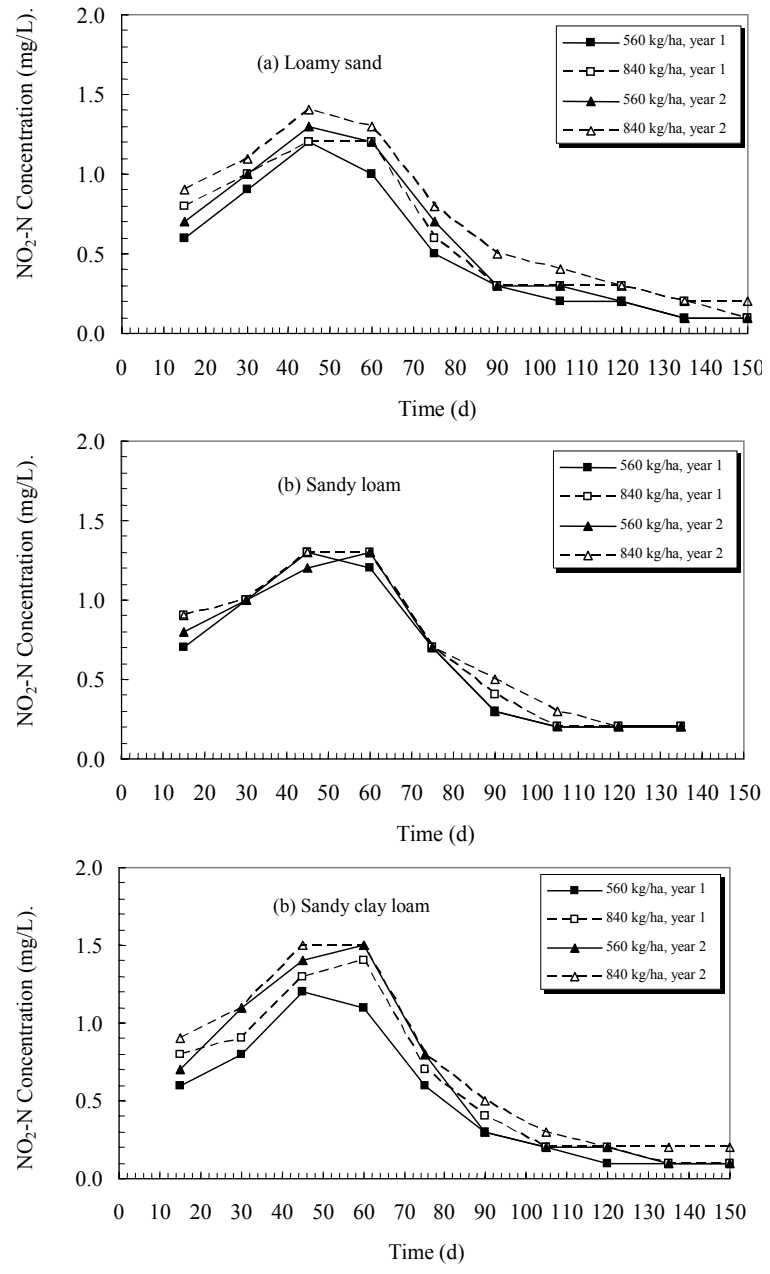

Fig. 6: Nitrite nitrogen concentration in the leachates

Ammonia volatilization: The measured values of volatized ammonia are presented in Fig. 8. The release of ammonia from the whey was initially high up to day 15 but declined markedly with time and ceased on day 75. The whey application rate and soil type did not affect the amount of ammonia released but there was a 

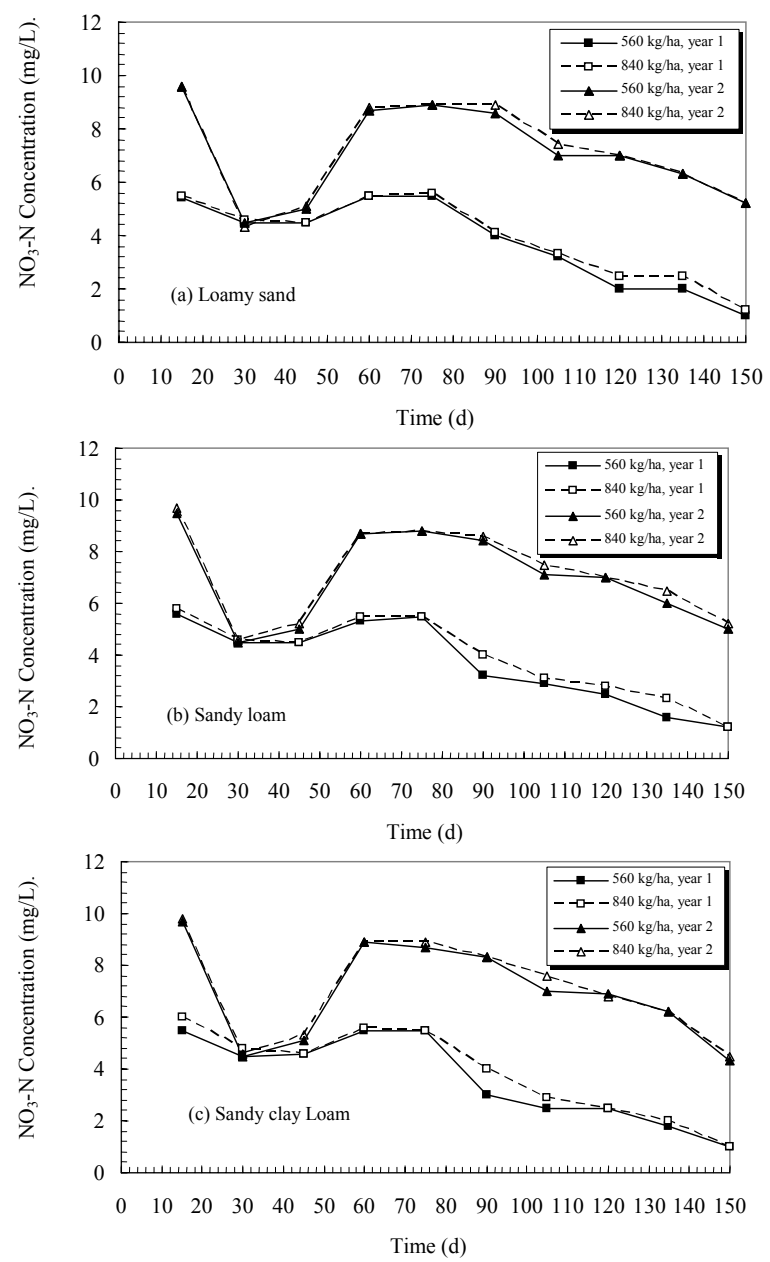

Fig. 7: Nitrate nitrogen concentration in the leachates

slight increase in ammonia volatilization in the second season.

\section{DISCUSSION}

The nitrogen losses in the leachates and air are presented in Table 5. The results showed that the whey application rate and the soil type did not have any significant effect on the ability of the soil to remove organic nitrogen. The amount of organic nitrogen lost in the leachate ranged from 9.5 to $13.0 \mathrm{mg}$. The organic nitrogen losses represent $3.02-4.14 \mathrm{~kg} \mathrm{ha}^{-1}(0.54-$ $0.74 \%$ of the organic nitrogen or $0.52-0.71 \%$ of the total nitrogen). Boswell et al. ${ }^{[11]}$ reported that the leaching losses of nitrogen occur when soils contain a significant quantity of nitrogen and water is moving downward through the soil. This, however, depends on the rate and time of waste or fertilizer application. Anderson et al. ${ }^{[12]}$ found organic nitrogen leaching

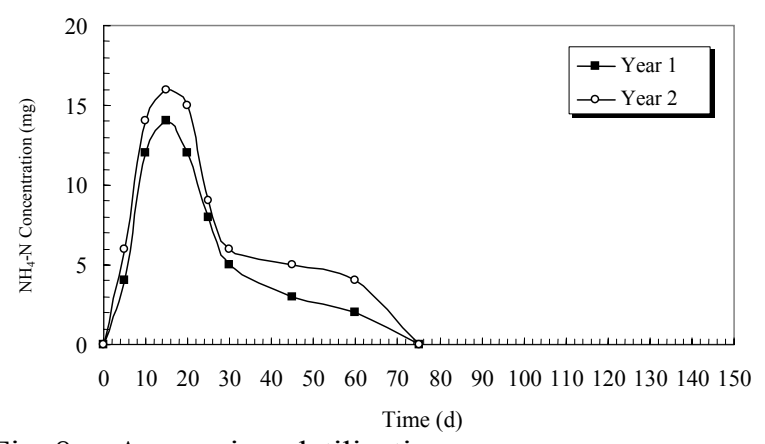

Fig. 8: Ammonia volatilization

increased with increasing temperature and $\mathrm{pH}$. It appears from the results that a continuous application of cheese whey may increase the concentration of organic nitrogen in the groundwater over time to a level which could be considered a pollution hazard.

The total amount of inorganic nitrogen $\left(\mathrm{NH}_{4}, \mathrm{NO}_{2}\right.$ and $\mathrm{NO}_{3}$ nitrogen) applied to each soil was $55 \mathrm{mg}$. However, between 59.00-76.30 mg were collected in the leachates, depending on the soil type and soil column depth. This indicated that both the nitrogen mineralization and nitrification processes have taken place in the soil profile. The production of nitrate reached its peak on day 45 while the production of nitrate reached its peak on day 60 , at which the nitrite concentrations started to decline. Kampbell et al. ${ }^{[13]}$ and Almasri and Kaluarachchi ${ }^{[14]}$ reported increased nitrate concentrations in ground water as a result of manure application and subsequent mineralization and nitrification. Although the concentrations of ammonium nitrogen and nitrate nitrogen in the applied cheese whey were similar ( 25 and $28 \mathrm{mg} \mathrm{L}^{-1}$, respectively), their concentrations in the leachate were significantly different (maximum 1.4 and $10.7 \mathrm{mg} \mathrm{L}^{-1}$, respectively). Ammonium ions are positively charged and because of the attractive forces between the ammonium ions and the negatively charged clay and organic colloids, they are held in these cation exchange sites and so move slowly with the soil water ${ }^{[15]}$. Nitrate ions are negatively charged and tend to be repelled by the similarly charged soil particles. The proportion of clay in the soil had some effect on the nitrate nitrogen concentration in the leachate. The higher the negative charge on clay particles in the soil, the higher the nitrate nitrogen concentration will be. Nitrate and nitrite are also soluble in water and move downward with the soil water. These resulted in the higher concentrations of nitrate nitrogen observed in the leachate. The concentration of the nitrate nitrogen in the leachates was below the maximum allowable level $\left(10 \mathrm{mg} \mathrm{L}^{-1}\right)$ in drinking water for humans, but was above the allowable 
concentration (5 $\left.\mathrm{mg} \mathrm{L}^{-1}\right)$ in drinking water for animals $^{[16]}$. Therefore, continuous application of whey at higher rates will pose a health hazard for both animals and humans. However, the presence of nitrite and nitrate in the ground water at high concentrations as a result of large applications of cheese whey may result in serious health problems for both animals and humans. Nitrite is known to cause cancer and blue baby syndrome (sudden death in young animals and babies). Amino compounds and ferric iron in the blood stream combines with $\mathrm{NO}_{2}$ instead of molecular oxygen.

$\mathrm{NO}_{2}+$ Amino Compounds $\rightarrow$ Nitrosamines

$$
\text { (powerful carcinogens) }
$$

$\mathrm{NO}_{2}+$ Hemoglobin Compounds $\rightarrow \underset{\text { (blue baby syndrome) }}{\text { Methemia }}$

Nitrate is known to cause health problems in humans and animals as well. These include abortion, muscle stiffness, abdominal pain, muscular weakness, infertility, lower weight gain, lack of coordination, diarrhea and reduced vitamin storage in the liver.

Volatilization was observed to be independent of both the soil type and the amount of whey applied to the soil surface. However, the amount of ammonia gas released from the soil in the second season was much higher than that released in the first season. In contrast to the findings of Mills et al. ${ }^{[17]}$ which states that about $70 \%$ of the $\mathrm{NH}_{3}-\mathrm{N}$ in commercial fertilizers volatilized within the first three days after application, the ammonia volatilization occurred more gradually in this study and ceased after 75 days. About $98 \%$ of the ammonia was released in the first 30 days. About 10.71 $\mathrm{g}$ of nitrogen was converted from ammonium to ammonia gas which was then lost to the atmosphere. This represents $3.41 \mathrm{~kg} \mathrm{ha}^{-1}(0.59 \%$ of the total nitrogen).

The low ammonia volatilization observed in this study could be due to several reasons. The high initial moisture content of the soil surface could have dissolved the ammonia $\left(\mathrm{NH}_{3}\right)$ and reduced ammonia volatilization as reported by Fenn and Escarzaga ${ }^{[18]}$. Another reason for the observed smaller amounts of volatilized $\mathrm{NH}_{3}$ in this study is that the air exchange used was too low $\left(320 \mathrm{~cm}^{3} \mathrm{~min}^{-1}\right.$ or $\left.0.03 \mathrm{VVM}\right)$. Terry et al. ${ }^{[18]}$ reported that rapid movement of air across the soil surface promoted $\mathrm{NH}_{3}$ volatilization by maintaining a low partial pressure of $\mathrm{NH}_{3}$ in the atmosphere adjacent to the soil. Also, the low air exchangeability may have increased the relative humidity $(\mathrm{RH})$ of the air and resulted in less $\mathrm{NH}_{3}$ volatilization. Terman et $a l .{ }^{[19]}$ and Terry ${ }^{[20]}$ pointed out that rapid movement of low RH air across the soil surface can promote rapid loss of soil moisture, thereby stimulating $\mathrm{NH}_{3}$ evolution. Another reason is the low $\mathrm{pH}$ of the soil (the three soils had a $\mathrm{pH}$ less than 7). Boswell et al. ${ }^{[11]}$ reported that soil $\mathrm{pH}>7.0$ increased ammonia losses by increasing the $\mathrm{NH}_{3} / \mathrm{NH}_{4}{ }^{+}$ratio.

\section{CONCLUSION}

The leaching and volatilization processes were monitored over a period of five months each season. The concentrations of nitrogenous compounds in the leachates obtained from three soils decreased with time. The soil type and whey application rate did not have any significant effect on the soil removal efficiency of these compounds. However, higher concentrations were observed in the second season of application. The decline in the concentrations of ammonium nitrogen the initial increase in the nitrite nitrogen and nitrate nitrogen concentrations in the leachates indicated that the nitrification process had taken place. The organic nitrogen losses in the leachates were $3.02-4.14 \mathrm{~kg} \mathrm{~h}^{-1}$ (0.54-0.74\% of the initial total nitrogen). The total inorganic $\left(\mathrm{NH}_{4}, \mathrm{NO}_{2}, \mathrm{NO}_{3}\right)$ nitrogen losses in the leachate were $59-76 \mathrm{mg}$ which is higher than the initial concentration of $55 \mathrm{mg}$ indicating that the mineralization process had taken place. Volatilization of $\mathrm{NH}_{3}$ was independent of soil type and whey application rate. About $3.41 \mathrm{~g}^{-1} \mathrm{ha}^{-1}(0.59 \%$ of the initial total nitrogen) of nitrogen was lost to the atmosphere through volatilization. Nitrite and nitrate are highly soluble and easily leach out of soil solution. Therefore, continuous application of cheese whey at higher rates may result in ground water contamination and eventually becomes a threat to human and animal health. Additional research is needed to assess the role of plants in the removal of $\mathrm{NH}_{4}$ and $\mathrm{NO}_{3}$ nitrogen and the impact of continuous whey application on the soil properties.

\section{ACKNOWLEDGEMENT}

This study was financially supported by the National Science and Engineering Research Council (NSERC) of Canada.

\section{REFERENCES}

1. Ghaly, A.E., D.R. Ramkumar, S.S. Sadaka and J.P. Rochon, 1999. Effect of pH control and reseeding on the performance of a two-stage mesophilic anaerobic digester operating on acid cheese whey. Can. Agril. Engg., 42: 173-183. 
2. FAO, 2005. FAO Year Book. Food and Agricultural Organization of the United Nations. Rome, Italy.

3. Ghaly, A.E. and J.P. Singh, 2006. Reduction of microbial population in cheese whey in a single and conventional reactors. Am. J. Biochem. and Biotech., 2: 89-96.

4. Ghaly, A.E., E. Echiegu and J.B. Pyke, 1988. Pollution Potential of Land Disposal of Cheese Whey. In: Proceedings of the Food Processing Wastes Conference, Georgia Institute of Technology, Atlanta, pp: 55-67.

5. Ben Hassan, R.M. and A.E. Ghaly. 1995. Continuous production of single cell protein from cheese whey lactose using Klyveromyces fragilis. Trans. of the ASAE, 38: 1121-1127.

6. Ghaly, A.E. and R.K. Singh, 1985. Land Application of Cheese Whey. In: Proc. the 5th Intl. Symp. on Agricultural Wastes. American Society of Agricultural Engineers, Chicago, Michigan, pp: 546-553.

6. Ghaly, A.E. and R.K. Singh, 1989. Pollution potential reduction of Cheese Whey through yeast fermentation. Appl. Biochem. Biotech. J., 22: 181203.

7. Black, C.A., D.D. Evans, L.E. Ensminger, J.L. White and F.E. Clark, 1965. Methods of Soil Analysis. American Society of Agronomy Publishers. Madison, Wisconsin.

8. Environment Canada, 2005. The Weatheroffice, Environment Canada, Halifax, Nova Scotia.

9. APHA, 1998. Standard Methods for the Examination of Water and Wastewater. Am. Public Health Association, New York, New York.

10. Zein El Abedin, T., 1993. Manurial nutrients transformation and transport in the soil-water complex. Ph.D. Thesis, Agricultural Engineering Department, Technical University of Nova Scotia, Halifax, Nova Scotia.
11. Boswell F.C., J.J. Meisinger and N.L. Case, 1985. Fertilizer Technology and Use. 3rd Edn. Soil Science Society of America, Madison, Wisconsin, pp: 229-292.

12. Andersson, S., S.I. Nilsson and P. Saetre, 2000. Leaching of dissolved organic carbon (DOC) and dissolved organic nitrogen (DON) in mor humus as affected by temperature and $\mathrm{pH}$. Soil Biol. Biochem., 32: 1-10.

13. Kampbell, D.H., Y.J. An, K.P. Jewell and J.R. Masoner, 2003. Groundwater quality surrounding Lake Texoma during short-term drought conditions. Environ. Poll., 125: 183-191.

14. Almasri, M.N., J.J. Kaluarachchi, 2004. Assessment and management of long-term nitrate pollution of ground water in agriculture dominated watersheds. J. Hydrol., 298: 225-245.

15. Loehr, R.C. Pollution Control for Agriculture. Academic Press Inc., New York, New York.

16. Culey, B. and G. Barnett, 1980. Manure and the Environment. Agricultural Canada Publications. Ottawa, Ontario.

17. Mills, H.A., A.V. Barker and D.N. Maynard. 1974. Ammonia volatilization from soils. Agron. J., 66: 355-358.

18. Fenn, L.B. and R. Escarzaga, 1976. Ammonium volatilization from surface application of ammonium compounds on calcareous soils. V. Soilwater content and method of nitrogen application. Soil Sci. Soc. of Am. J., 40: 537-541.

19. Terman, G.L., F. Parr and S.E. Allen. 1968. Recovery of nitrogen by corn from solid fertilizer and solutions. J. Agric. Food Chem., 16: 685-690.

20. Terry, R.E. and R.L. Tate. 1978. Denitrification as a pathway for nitrate removal from organic soils. Soil Sci., 129: 162-166. 